\title{
Are the methylenetetrahydrofolate reductase 1298 and 677 gene polymorphisms related to optic glioma and hamartoma risk in neurofibromatosis type 1 patients?
}

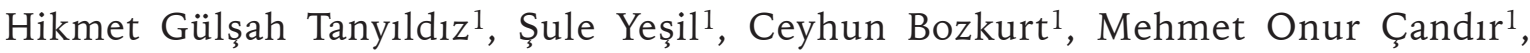 \\ Sibel Akpınar-Tekgündüz ${ }^{1}$, Şule Toprak ${ }^{1}$, Deniz Yüksel², Gürses Şahin ${ }^{1}$ \\ ${ }^{1}$ Division of Pediatric Hematology Oncology and ${ }^{2}$ Division of Pediatric Neurology, Department of Pediatrics, Dr. Sami Ulus \\ Maternity and Children's Training and Research Hospital, Ankara, Turkey.E-mail: g_oktay4910@yahoo.com \\ Received: 5 April 2016, Revised: 17 May 2016, Accepted: 9 June 2016
}

SUMMARY: Tanyıldız HG, Yeşil Ş, Bozkurt C, Çandır MO, Akpınar-Tekgündüz S, Toprak Ş, Yüksel D, Şahin G. Are the methylenetetrahydrofolate reductase 1298 and 677 gene polymorphisms related to optic glioma and hamartoma risk in neurofibromatosis type 1 patients? Turk J Pediatr 2016; 58: 152-158.

The methylenetetrahydrofolate reductase (MTHFR) gene plays a key role in carcinogenesis through its effects on DNA synthesis and methylation and also has a significant role in the etiology of many disorders, such as diabetes, migraine, and cardiovascular disease. Neurofibromatoses (NF) are autosomal dominant inherited diseases that can affect tissues such as bone and skin and predispose individuals to tumor development in various parts of the nervous system or body. Optic nerve glioma and brain tumors are common in children with NF, and leukemia and lymphoma incidence is also higher than normal. We therefore aimed to investigate the possible relationship between the MTHFR gene polymorphism and accompanying tumors such as neurofibroma, hamartoma, and optic glioma in children with NF1 found to have the MTHFR 677 and MTHFR 1298 gene polymorphism in this study. We included 55 pediatric patients diagnosed with NF1 between 2005 and 2014 in the study group. The control group included 44 healthy subjects without acute or chronic disease findings. A significant relationship was found between the MTHFR A1298C polymorphism and the incidence of optic glioma $(\mathrm{p}=0.014)$ (AA vs. AC: OR 11, 95\% CI 1.27-95.17; AA vs. CC: OR 7.33, 95\% CI 0.35-150.70). We also found a significant relationship between the MTHFR C1298C polymorphism and the incidence of hamartoma $(p=0.019)$ (AA vs. AC: OR 2.12, 95\% CI 0.662-6.809; $\mathrm{p}=0.203$ ). Epilepsy incidence was high in subjects with MTHFR C677C. The MTHFR A1298C, C1298C, and C677C gene polymorphisms can be associated with a higher optic glioma, hamartoma, and epilepsy incidence, respectively, in patients diagnosed with neurofibromatosis type 1 .

Key words: MTHFR gene polymorphism, neurofibromatosis type 1.

Folate plays an important role in DNA synthesis and methylation, and its deficiency leads to disruption of the DNA repair mechanism. The key enzyme that controls folate and methionine, which are important in DNA methylation and folic acid, homocysteine, and nucleotide synthesis, is 5,10-methylenetetrahydrofolate reductase (MTHFR). MTHFR catalyzes the conversion of methylenetetrahydrofolate to tetrahydrofolate, and its gene is located in 1p36.31,2. Disorders in folate metabolism are known to cause DNA chain breaks, chromosomal translocations, deletions and to damage DNA replication. They also increase the risk for cancer by causing hypomethylation of DNA and activation of proto-oncogenes. It is therefore thought that polymorphisms in the MTHFR gene cause a decrease in MTHFR enzyme activity and possibly cause a genetic predisposition to various cancers by affecting the regulation of folate metabolism ${ }^{3-7}$. MTHFR has several variants, and the polymorphisms 
most commonly affecting enzyme activity have been reported as $677 \mathrm{C}>\mathrm{T}, 1298 \mathrm{~A}>\mathrm{C}, 1059$ $\mathrm{T}>\mathrm{C}, 1317 \mathrm{~T}>\mathrm{C}$, and $1793 \mathrm{G}>\mathrm{A}$. The two common polymorphisms of MTHFR C677 and A1298C are reported to be associated with cerebrovascular diseases, venous thrombosis, neural tube defects, diabetes, cancer, and migraine. Genetic defects as a result of MTHFR gene polymorphism can adversely affect the development of the central nervous system and cause a predisposition to central nervous system tumors $^{8-13}$. The incidence of brain tumors is also increased in NF1 patients; therefore, in this study, we investigated the relationship between the accompanying tumors in NF1 patients and the MTHFR gene analysis results.

\section{Material and Methods}

We included 55 pediatric patients diagnosed with Neurofibromatosis type 1 and followed regularly by oncology, neurology, dermatology and ophthalmology between 2005 and 2014 in the study group. The physical examination and imaging results of the patients at presentation and follow-up were recorded. Family history, the number and size of cafe-au-lait spots, Lisch nodules, neurofibromas, axillary and inguinal freckling, MR results (hamartoma and optic glioma), and the presence of epilepsy or an additional anomaly were considered. We evaluated the relationship of the clinical spectrum of the disease with the results of the MTHFR gene analysis of the patients at the time of diagnosis. Clinical findings of NF1 patients with hamartoma and optic glioma have been presented in separate Table I and II. The genomic DNA of the patients was isolated from peripheral blood. The QIAamp DNA Blood Mini Kit (Qiagen Inc.) was used for this procedure and the samples were kept at $-20^{\circ} \mathrm{C}$ until the PCR stage. The PCR and minisequencing primary and probes were designed for MTHFR gene polymorphisms. Following the mini-sequencing reaction, fluoresceinlabeled products were analyzed using the $A B I$ 3130 Genetic Analyzer (Applied Biosystems) and fragment analysis program GeneMapper 4.0 software (Applied Biosystems Co. Ltd., USA). The 677 and 1298 gene polymorphisms were investigated during the MTHFR gene analysis. This study was approved by the Ethics Committee.

\section{Statistical analysis}

The SPSS for Windows 15 software program was used for data analysis. Descriptive statistics were shown as number of cases and percentages. Nominal variables were evaluated with the Pearson Chi-Square or Fisher's exact test. Odds ratio and the related confidence intervals were calculated for significant variables. The Hardy-Weinberg inequality principle was used to determine whether the allele incidence was balanced in the population. Results at $\mathrm{p}<0.05$ were accepted as statistically significant.

\section{Results}

The median age of the 55 Neurofibromatosis type 1 patients included in the study was 7.5 years (1-17), and the median followup duration was 6 years (2-9). The control group included healthy subjects without acute or chronic disease findings $(n=44)$ and had similar demographic features with NF1 patients. In the control group, the following incidences were present: CC677 (52.3\%; $\mathrm{n}=23)$, CT677 (38.6\%; $\mathrm{n}=17)$, TT677 (9.1\%; $\mathrm{n}=4)$, AA1298 (47.7\%; $\mathrm{n}=21)$, AC 1298 $(45.5 \% ; n=20)$, and CC1298 (6.8\%; $n=3)$. In the neurofibromatosis group, the following incidences were present: AA1298 (43.6\%; $n=24)$, AC (49.1\%; $n=27)$, CC $(7.3 \% ; n=4)$, CC677 (41.8\%; $n=23)$, CT $(49.1 \% ; n=27)$, and TT $(9.1 \% ; n=5)$. There was no patient homozygous for both gene polymorphisms. There were 11 compound heterozygote NF1 patients. Both the MTHFR 677 and MTHFR 1298 genes were normal in 5 NF patients. A family history of Neurofibromatosis type 1 was present in 38 (70.4\%) patients. A Lisch nodule was present in 23 cases $(42.5 \%)$ and freckling in 26 cases $(48.1 \%)$. Clinical features of epilepsy $(9.2 \%)$ were present in 5 cases. Four of 5 epilepsy patients had hamartoma and only one epilepsy patient had optic glioma. Optic glioma was found in $11(18.5 \%)$ patients and hamartoma in $24(44.4 \%)$ patients. Five of 55 patients had both hamartoma and optic glioma. Median follow-up time was 5 (2-7) years for hamartoma patients and 3 (1-6) years for optic glioma patients with NF1. Three of 11 optic glioma patients had chemotherapy because of progressive disease. In one patient with progressive disease, we added imatinib treatment besides routine chemotherapy drugs 
Table I. Clinical Findings of NF1 Patients with Hamartoma

\begin{tabular}{|c|c|c|c|c|c|c|c|c|c|c|c|}
\hline $\mathrm{N}$ & G & $\begin{array}{c}\text { Age } \\
\text { (year) }\end{array}$ & $\begin{array}{l}\text { Café } \\
\text { au- } \\
\text { lait }\end{array}$ & Freckling & $\begin{array}{l}\text { Lisch } \\
\text { nodules }\end{array}$ & Neurofibroma & Hamartoma & $\begin{array}{c}\text { Optic } \\
\text { Glioma }\end{array}$ & Epilepsy & $\begin{array}{c}\text { MTHFR } \\
1298\end{array}$ & $\begin{array}{c}\text { MTHFR } \\
677\end{array}$ \\
\hline 1 & M & 3.5 & + & - & + & - & + & - & + & $\mathrm{CC}$ & $\mathrm{CC}$ \\
\hline 2 & $\mathrm{~F}$ & 2 & + & + & + & - & + & - & - & $\mathrm{AC}$ & $\mathrm{CC}$ \\
\hline 3 & $\mathrm{~F}$ & 12 & + & + & - & + & + & - & - & AC & $\mathrm{CC}$ \\
\hline 4 & M & 10 & + & - & + & - & + & - & - & AA & $\mathrm{CT}$ \\
\hline 5 & M & 7 & + & - & + & - & + & + & - & AC & $\mathrm{CT}$ \\
\hline 6 & $\mathrm{~F}$ & 5 & + & + & + & - & + & - & - & $\mathrm{AC}$ & $\mathrm{CC}$ \\
\hline 7 & M & 4 & + & - & - & - & + & + & - & $\mathrm{AC}$ & $\mathrm{CC}$ \\
\hline 8 & M & 10 & + & - & + & + & + & - & - & $\mathrm{AC}$ & $\mathrm{CT}$ \\
\hline 9 & M & 10 & + & - & - & - & + & - & - & AC & $\mathrm{CT}$ \\
\hline 10 & M & 1 & + & - & - & - & + & - & - & $\mathrm{CC}$ & CT \\
\hline 11 & $\mathrm{M}$ & 5 & + & + & + & - & + & - & - & $\mathrm{CC}$ & $\mathrm{CC}$ \\
\hline 12 & $\mathrm{~F}$ & 2 & + & - & - & + & + & - & + & AA & $\mathrm{CC}$ \\
\hline 13 & $\mathrm{~F}$ & 15 & + & + & - & - & + & - & - & AC & $\mathrm{CC}$ \\
\hline 14 & $\mathrm{M}$ & 17 & + & + & + & - & + & - & - & $\mathrm{AA}$ & $\mathrm{CT}$ \\
\hline 15 & $\mathrm{~F}$ & 11 & + & - & - & - & + & - & + & $\mathrm{AC}$ & $\mathrm{CC}$ \\
\hline 16 & $\mathrm{~F}$ & 8 & + & + & + & - & + & + & - & AC & $\mathrm{CC}$ \\
\hline 17 & $\mathrm{~F}$ & 2 & + & + & - & + & + & - & - & $\mathrm{AA}$ & CT \\
\hline 18 & $\mathrm{M}$ & 6 & + & + & - & - & + & + & - & $\mathrm{CC}$ & $\mathrm{CC}$ \\
\hline 19 & $\mathrm{~F}$ & 16 & + & + & + & - & + & - & - & $\mathrm{AC}$ & CT \\
\hline 20 & $\mathrm{M}$ & 13 & + & - & + & + & + & - & - & AA & CT \\
\hline 21 & $\mathrm{~F}$ & 2 & + & - & - & + & + & - & - & AA & CT \\
\hline 22 & $\mathrm{M}$ & 14 & + & + & + & - & + & - & - & AA & TT \\
\hline 23 & $\mathrm{~F}$ & 6 & + & + & - & - & + & - & + & $\mathrm{AC}$ & $\mathrm{CC}$ \\
\hline 24 & $\mathrm{M}$ & 14 & + & + & + & - & + & + & - & $\mathrm{AC}$ & $\mathrm{CT}$ \\
\hline
\end{tabular}

F: female; G: gender; M: male; N: patient number; +: yes; -: no.

including vincristine, carboplatin and etoposide. The others $(n=8)$ had stabile disease without chemotherapy. Optic glioma patients had normal visual field results except one received imatinib due to progressive disease. The hamartoma incidence was significantly lower in patients with normal MTHFR A1298A than those who were homozygotes $(p=0.019)$. The risk of optic glioma was 11 times higher in those with MTHFR A1298C than those with MTHFR A1298A (95\% CI: 1.27-95.17) $(\mathrm{P}=0.014)$. Optic glioma was 7.3 times more common in those with CC 1298 than in those with AA1298 (95\% CI: 0.35-150.70) $(p=0.279)$. The allele frequencies were distributed regularly in those with MTHFR 1298 and MTHFR 677 and in the control group. MTHFR 677 and 1298 genotype and allele frequency in NF1 patients and controls are listed in Tables III and IV.

\section{Discussion}

MTHFR plays a major role in homocysteine formation, nucleotide synthesis, and methylation reactions. Changes in MTHFR enzyme activity affect the methylation status of DNA and play a role in carcinogenesis by altering DNA stability and gene expression. Polymorphisms within the gene that code the MTHFR enzyme and that affect the gene product are a major issue of interest at present. However, it should not be forgotten that MTHFR polymorphisms can vary between individuals due to race, ethnic origin, or other cellular polymorphic structures ${ }^{1,14}$.

Neurofibromatosis consists of two different conditions (NF1 and NF2), and each is the result of a different gene disorder. In addition to neurofibroma, malignant tumors such as leukemia, soft tissue tumors, brain tumors, 


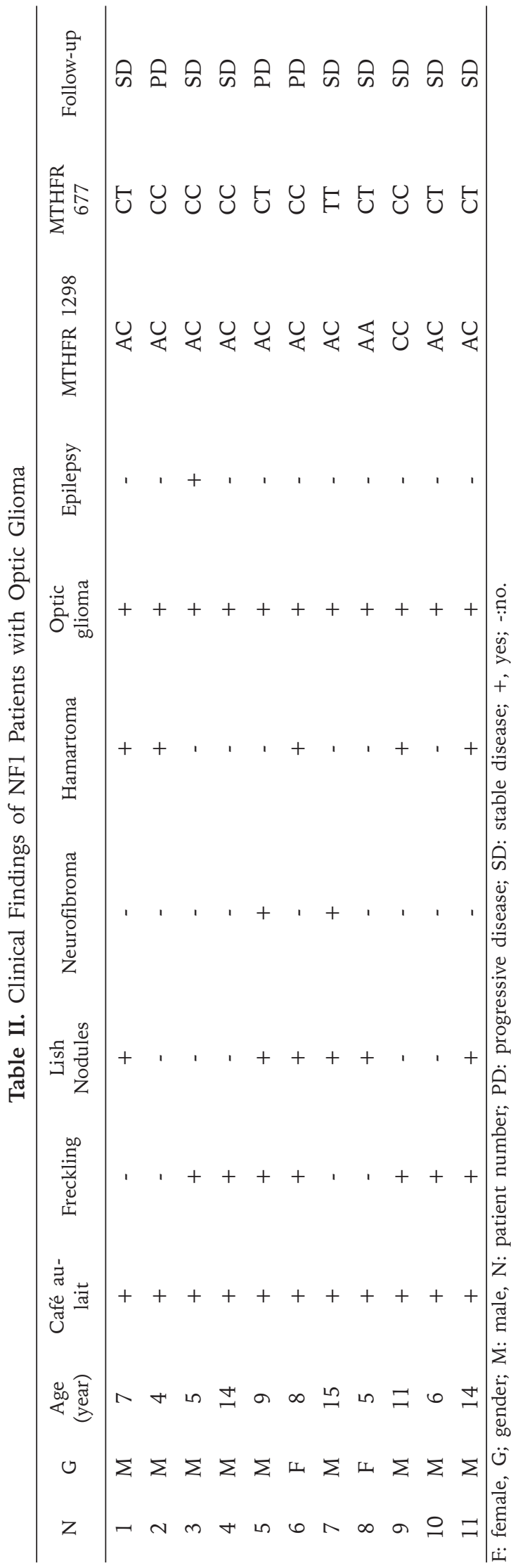

and neuroblastoma can also develop in NF1 cases $^{15-18}$. We aimed to detect the MTHFR gene polymorphisms that may predict tumor development risk during the follow-up of NF1 patients as the disorder has a genetic basis. We showed that MTHFR 1298 and MTHFR 677 gene polymorphisms were related to central nervous system benign tumors (hamartoma and optic glioma) and disorders (epilepsy) in NF1 patients. Especially, in the respect of MTHFR 1298 gene polymorphism, it was shown that hamartoma is significantly more common in patients homozygous for MTHFR 1298 CC $(\mathrm{p}=0.019)$. Beside this; hamartoma was 2.1 times more common in patients heterozygous for MTHFR 1298 but it was not statistically significant $(p=0.203)$. Secondly we observed that optic glioma was 11 times more common in patients heterozygous for MTHFR 1298 AC $(p=0.014)$ while 7.3 times more common in those homozygous for $1298 \mathrm{CC}(\mathrm{p}=0.279)$.

The MTHFR enzyme activity decreases with an MTHFR 1298 mutation as in other MTHFR mutations. Although some studies suggest that an MTHFR 1298 enzyme defect is not as important as an MTHFR 677 gene defect, other articles support the opposite view. A homocysteine increase due to a MTHFR 1298 gene polymorphism has been suggested to be effective in the etiology of cases with a neural tube defect ${ }^{19}$. Some studies also suggest that a mutation in the MTHFR 1298 gene may play a role in the etiology of adult gastric and ovarian cancers $^{20,21}$. We similarly found an association between the incidence of hamartoma and optic glioma incidence and the MTHFR 1298 gene mutation in our study.

Conflicting results have been reported from studies on the relationship between MTHFR 677 polymorphism and cancer. The effects of the MTHFR 677 genotype on global DNA methylation and DNA synthesis can act to decrease or increase the cancer risk. Gastric and esophagus cancer risk has been reported to increase ${ }^{22}$ whereas colorectal cancer, lung cancer and leukemia risk has been reported to decrease with the MTHFR 677 polymorphism ${ }^{23-25}$. The effect of the MTHFR C677T polymorphism on brain tumors remains poorly understood. Izmirli et al. $^{8}$ showed that the incidence of the 677 TT genotype has been found to be higher than normal in 74 high-grade glioma cases. Xu et 
Table III. MTHFR 677 Genotype and Allele Frequency in NF1 Patients and Controls

\begin{tabular}{lccccc}
\hline MTHFR 677 & NF1 patients $(\mathrm{n}=55)$ & Controls $(\mathrm{n}=44)$ & OR & $95 \%$ CI & P-value \\
\hline CC genotype & 23 & 23 & 0.67 & $0.29-1.46$ & 0.300 \\
CT genotype & 27 & 17 & 1,53 & $0.68-3.42$ & 0.298 \\
TT genotype & 5 & 4 & 1.00 & $0.25-3.97$ & 1.000 \\
C allele & 32 & 21 & 1.52 & $0.69-3.38$ & 0.300 \\
T allele & 50 & 40 & 1.00 & $0.25-3.97$ & 1.000 \\
\hline
\end{tabular}

Table IV. MTHFR 1298 Genotype and Allele Frequency in NF1 Patients and Controls

\begin{tabular}{lccccc}
\hline MTHFR 1298 & NF1 patients $(\mathrm{n}=55)$ & Controls $(\mathrm{n}=44)$ & OR & $95 \%$ CI & P-value \\
\hline AA genotype & 24 & 21 & 0.848 & $0.38-1.85$ & 0.685 \\
AC genotype & 27 & 20 & 1.16 & $0.52-2.56$ & 0.719 \\
CC genotype & 4 & 3 & 1.07 & $0.23-5.06$ & 1.000 \\
A allele & 31 & 23 & 0.93 & $0.20-4.40$ & 1.000 \\
C allele & 51 & 41 & 1.18 & $0.53-2.61$ & 0.685 \\
\hline
\end{tabular}

al. ${ }^{26}$ reported MTHFR C677T genotype carriers were more susceptible to meningioma when compared with the CC genotype carriers. It was emphasized that MTHFR C677T variant is a risk factor for survival in adult glioblastoma multiforme patients ${ }^{27}$. Hovewer, the effect of MTHFR C677T polymorphism on risk of gliomas is still uncertain. The evidence from meta-analysis of Lu et al. ${ }^{28}$ supports that there is no association between MTHFR $677 \mathrm{C}>\mathrm{T}$ polymorphism and risk of gliomas. It is not possible to fully explain the contrasting findings in different types of cancer. Decreased MTHFR activity is said to be associated with lifetime exposure to global DNA hypomethylation. Global DNA hypomethylation is observed in early stages of tumor development and leads to cancer. This becomes important in tissues with significant DNA synthesis such as the colon, rectum, epithelium, and bone marrow as it is dominant to hypomethylation ${ }^{29-34}$. When the MTHFR 677 mutation was investigated as a second gene polymorphism, we noticed a significantly increased epilepsy incidence rather than cancer incidence in patients $(n=5)$ with MTHFR 677 CC. The statistical results may have been influenced by the small number of patients. Also, it may not be appropriate to explain this difference only with the MTHFR 677 and 1298 gene polymorphisms as there may also be polymorphisms of other enzymes in the MTHFR gene and other methylation pathways. One should also take into account many other factors, such as dietary habits, environmental differences and genetic factors. For example betaine, which is one of the methyl donors, affects DNA methylation in organisms. Methyl transfer in the central nervous system is dependent on the B12-folic acid MTHFR pathway system in contrast with other tissues. As a result of betaine inactivity here, MTHFR gene deficiency primarily affects the central nervous system ${ }^{35,36}$. Environmental factors and gene genotypes involved in carcinogenesis may account for this difference. Therefore, genetic susceptibility to cancer has been a research focus in the scientific community. Genetic epidemiologic studies of single nucleotide polymorphisms can uncover the relationships between candidate genes and cancer risk. However, individual studies on the relationship between MTHFR C677T and MTHFR A1298C polymorphisms and cancer risk have generated inconsistent results partly due to small sample sizes. Therefore, meta-analysis studies can be useful to solve problems caused by the low statistical power in a single study and can enable more robust conclusions. Our present study including 55 patients estimated the potential role of MTHFR 677 and 1298 gene polymorphisms in NF1 patients with hamartoma and optic glioma. However the patient number of the study group is small and 11 optic glioma patients are not adequate. This is major limitation of our study.

In conclusion, MTHFR gene polymorphisms 
can play a role in the etiopathogenesis of NF1 cases accompanied by lesions of the central nervous system. Similar to the MTHFR 677 gene, the MTHFR 1298 gene may also have a role in the clinical presentation of the disorder. The evaluation of MTHFR gene polymorphism in disorders accompanied by central nervous system pathologies may contribute to the explanation of the relationship. The results of this first study to investigate MTHFR gene polymorphisms in NF1 patients will therefore guide clinicians in the future.

\section{REFERENCES}

1. Dikmen M. Metilentetrahidrofolat redüktaz (MTHFR) enziminin moleküler biyolojisi ve hastalıklarla ilişkisi. Kocatepe Tip Dergisi 2004; 5: 2: 9-16.

2. Çetintaş VB, Avc1 ÇB, Süslüer SY, Eroğlu Z, Gündüz C. Meta-analiz: Türk toplumunda MTHFR c.677C $>$ T polimorfizmi ve kanser ilişkisi. Ege Tıp Dergisi 2012; 51: $221-228$

3. Rosenblatt DS. Methylenetetrahydrofolate reductase. Clin Invest Med 2001; 24: 56-59.

4. Homberger A, Linnebank M, Winter C, et al. Genomic structure and transcript variants of the human methylenetetrahydrofolate reductase gene. Eur J Hum Genet 2000; 8: 725-729.

5. Bagley PJ, Selhub J. A common mutation in the methylenetetrahydrofolate reductase gene is associated with an accumulation of formylated tetrahydrofolates in red cells. Proc Natl Acad Sci USA 1998; 95: 1321713220.

6. Bailey LB, Duhaney RL, Maneval DR, et al. Vitamin B-12 status in inversely associated with plasma homocysteine in young women with C677T and/ or A1298C methylenetetrahydrofolate reductase polymorphisms. J Nutr 2002; 132: 1872-1878.

7. Kim Y. Methylenetetrahydrofolate reductase polymorphisms, folate, and cancer risk: A paradigm of gene-nutrient interactions in carcinogenesis. Nutr Rev 2000; 58: 205-209.

8. İzmirli M, Aldemir Ö, Göğebakan B, Alptekin D. MTHFR 677 C > T Polimorfizmi ile ilintili olduğu düşünülen hastalıklara dair Türk populasyonundaki çalışmalar. Dicle Tıp Dergisi 2014; 41: 244-256.

9. Goyette P, Rozen R. The thermolabile variant $677 \mathrm{C}-->\mathrm{T}$ can further reduce activity when expressed in cis with severe mutations for human methylenetetrahydrofolate reductase. Hum Mutat 2000; 16: 132-138.

10. Yang QH, Botto LD, Gallagher M, et al. Prevalence and effects of gene-gene and gene-nutrient interactions on serum folate and serum total homocysteine concentrations in the United States: findings from the third National Health and Nutrition Examination Survey DNA Bank. Am J Clin Nutr 2008; 88: 232-246.

11. Robien K, Ulrich CM. 5,10-Methylenetetrahydrofolate reductase polymorphisms and leukemia risk: a HuGE minireview. Am J Epidemiol 2003; 153: 571-582.
12. Kupferminc MJ, Eldor A, Steinman N, et al. Increased frequency of genetic thrombophilia in women with complications of pregnancy. N Engl J Med 1999; 340: 9-13.

13. Wenstrom KD, Johanning GL, Johnston KE, DuBard M. Association of the C677T methylenetetrahydrofolate reductase mutation and elevated homocysteine levels with congenital cardiac malformations. Am J Obstet Gynecol 2001; 184: 806-812.

14. Izmirli M. A literature review of MTHFR (C677T and A1298C polymorphisms) and cancer risk. Mol Biol Rep 2013; 40: 625-637.

15. Schwahn B, Rozen R. Polymorphisms in the methylenetetrahydrofolate reductase gene: clinical consequences. Am J Pharmacogenomics 2001; 1: 189201.

16. Ozarda Y, Sucu DK, Hizli B, Aslan D. Rate of T alleles and TT genotype at MTHFR $677 \mathrm{C}>\mathrm{T}$ locus or $\mathrm{C}$ alleles and CC genotype at MTHFR $1298 \mathrm{~A}>\mathrm{C}$ locus among healthy subjects in Turkey: impact on homocysteine and folic acid status and reference intervals. Cell Biochem Funct 2009; 27: 568-577.

17. Hekim N, Ergen A, Yaylim I, et al. No association between methylenetetrahydrofolate reductase C677T polymorphism and breast cancer. Cell Biochem Funct 2007; 25: 115-117.

18. Küçükhüseyin Ö, Kurnaz Ö, Akadam-Teker AB, Narter F, Yılmaz-Aydoğan H, İsbir T. Effects of the MTHFR C677T polymorphism on prostate specific antigen and prostate cancer. Asian Pac J Cancer Prev 2011; 12: 2275-2278.

19. Botto LD, Yang Q. 5,10-Methylenetetrahydrofolate reductase gene variants and congenital anomalies: a HuGE review. Am J Epidemiol 2000; 151: 862-877.

20. Shen H, Newmann AS, Hu Z, et al. Methylenetetrahydrofolate reductase polymorphisms/ haplotypes and risk of gastric: a case-control analysis in China. Oncol Rep 2005; 13: 355-360.

21. Song CX, Ping L, Ting W. Folate, MTHFR C677T and A1298C polymorphisms with the relationship with ovarian cancer risk among Chinese females. Afr J Microbiol Res 2012; 6: 4761-4766.

22. Larsson SC, Giovannucci E, Wolk A. Folate intake, MTHFR polymorphisms, and risk of esophageal, gastric, and pancreatic cancer: a meta-analysis. Gastroenterology 2006; 131: 1271-1283.

23. Födinger M, Hörl WH, Sunder-Plassmann G. Molecular biology of 5,10-methylenetetrahydrofolate reductase. J Nephrol 2000; 13: 20-33.

24. Skibola CF, Smith MT, Kane E, et al. Polymorphisms in the methylenetetrahydrofolate reductase gene are associated with susceptibility to acute leukemia in adults. Proc Natl Acad Sci USA 1999; 96: 12810-12815.

25. Wang $\mathrm{H}$, Wang J, Zhao L, Liu X, Mi W. Methylenetetrahydrofolate reductase polymorphisms and risk of acute lymphoblastic leukemia-evidence from an updated meta-analysis including 35 studies. BMC Med Genet 2012; 13: 77. 
26. Xu C, Yuan L, Tian H, Cao H, Chen S. Association of the MTHFR C677T polymorphism with primary brain tumor risk. Tumour Biol 2013; 34: 3457-3464.

27. Linnebank M, Semmler A, Moskau S, Smulders Y, Blom $\mathrm{H}$, Simon M. The methylenetetrahydrofolate reductase (MTHFR) variant c.677C $>\mathrm{T}$ (A222V) influences overall survival of patients with glioblastoma multiforme. Neuro Oncol 2008; 10: 548-552.

28. Lu Q, Dai D, Zhao W, et al. Association between MTHFR $677 \mathrm{C}>\mathrm{T}$ polymorphism and risk of gliomas: evidence from a meta-analysis. Tumour Biol 2013; 34: 2801-2807.

29. Franco RF, Simões BP, Tone LG, Gabellini SM, Zago MA, Falcão RP. The methylenetetrahydrofolate reductase C677T gene polymorphism decreases the risk of childhood acute lymphocytic leukaemia. Br J Haematol 2001; 115: 616-618.

30. Wiemels JL, Smith RN, Taylor GM, Eden OB, Alexander FE, Greaves MF. Methylenetetrahydrofolate reductase (MTHFR) polymorphisms and risk of molecularly defined subtypes of childhood acute leukemia. Proc Natl Acad Sci USA 2001; 98: 4004-4009.

31. Ames, BN. Cancer prevention and diet: help from single nucleotide polymorphisms. Proc Natl Acad Sci USA 1999; 96: 12216-12218.
32. Matsuo K, Hamajima N, Suzuki R, et al. Methylenetetrahydrofolate reductase gene (MTHFR) polymorphisms and reduced risk of malignant lymphoma. Am J Hematol 2004; 77: 351-357.

33. Thompson JR, Gerald PF, Willoughby ML, Armstrong BK. Maternal folate supplementation in pregnancy and protection against acute lymphoblastic leukaemia in childhood: a case-control study. Lancet 2001; 358: 1935-1940.

34. Crott JW, Mashiyama ST, Ames BN, Fenech M. The effect of folic acid deficiency and MTHFR C677T polymorphism on chromosome damage in human lymphocytes in vitro. Cancer Epidemiol Biomarkers Prev 2001; 10: 1089-1096.

35. Huemer M, Mulder-Bleile R, Burda P, et al. Clinical pattern, mutations and in vitro residual activity in 33 patients with severe 5,10 methylenetetrahydrofolate reductase (MTHFR) deficiency. J Inherit Metab Dis 2016; 39: 115-124.

36. Jadavji NM, Deng L, Malysheva O, Caudill MA, Rozen R. MTHFR deficiency or reduced intake of folate or choline in pregnant mice results in impaired short-term memory and increased apoptosis in the hippocampus of wild-type offspring. Neuroscience 2015; 300: 1-9. 